\title{
Induksi Kalus pada Eksplan Daun Muda Tanaman Durian (Durio Zibethinus Murr.) Klon Baru Kamajaya dengan Kombinasi Zat Pengatur Tumbuh 2,4-D dan Kinetin secara In Vitro
}

\author{
Agung Rahmadi ${ }^{1}$, Noladhi Wicaksana ${ }^{2}$, Bambang Nurhadi ${ }^{3}$, Erni Suminar ${ }^{2}$, \\ Siti Rakhmah Tenrisui Pakki', dan Syariful Mubarok ${ }^{2^{*}}$ \\ ${ }^{1}$ Program studi Agroteknologi, Fakultas Sains dan Teknologi, UIN Sunan Gunung Djati \\ ${ }^{2}$ Program studi Agroteknologi, Fakultas Pertanian, Universitas Padjadjuaran \\ ${ }^{3}$ Departemen Teknologi Pangan, Fakultas Teknologi Industri Pertanian, Universitas Padjadjaran \\ ${ }^{4}$ Dinas Pangan dan Pertanian, Kota Cimahi \\ *Alamat korespondensi: syariful.mubarok@unpad.ac.id
}

\begin{abstract}
Callus induction of young leaves explant of new clone kamajaya of Durio zibethinus Murr. using the combination of 2,4-D and kinetin in vitro technique
\end{abstract}

Vegetative propagation of new Durian clone Kamajaya can be done with plant tissue culture as a modern technique for germplasm conservation. This study was conducted to determine the combination effects of 2,4-D and Kinetin for callus formation on Kamajaya durian leaves. The research was carried out at the Tissue Culture Laboratory, Faculty of Agriculture, Universitas Padjadjaran, Jatinangor. The experiment design used simple completely randomized design (CRD) factorial with two factors observed and descriptive analysis method. The first factor of plant growth regulator 2,4-D consisted of five different concentrations namely 1, 2, 3, 4, and $5 \mathrm{ppm}$. The second factor consisted of 3 different concentrations of Kinetin namely 0, 0,5 and $1 \mathrm{ppm}$. The result showed that 2 ppm 2,4-D, 3 ppm 2,4-D, 4 ppm 2,4-D, 2 ppm 2,4-D + 0,5 ppm kinetin produced rolled up explant of curved young durian leaves and swollen leaf bone. Meanwhile, the treatment of $5 \mathrm{ppm}$ 2,4-D, 2 ppm 2,4-D + 1 ppm kinetin, 5 ppm 2,4-D + 1 ppm kinetin produced rolled up explant of young durian leaves and formed the callus.

Keywords: 2,4-D, Durian Kamajaya, Kinetin, Tissue culture

\begin{abstract}
ABSTRAK
Perbanyakan durian klon baru Kamajaya secara vegetatif dapat dilakukan dengan teknik kultur jaringan sebagai teknik modern untuk konservasi plasma nutfah. Penelitian ini dilakukan untuk mengetahui pengaruh kombinasi 2,4-D dan Kinetin terhadap pembentukan kalus pada daun durian Kamajaya. Penelitian dilaksanakan di Laboratorium Kultur Jaringan, Fakultas Pertanian Universitas Padjadjaran, Jatinangor. Percobaan dirancang dengan Rancangan Acak Lengkap (RAL) faktorial dengan dua faktor yang diamati dan metode analisis deskriptif. Faktor pertama zat pengatur tumbuh 2,4-D terdiri dari konsentrasi yang berbeda yaitu 1, 2, 3, 4 dan 5 ppm. Faktor kedua terdiri dari 3 konsentrasi Kinetin yang berbeda yaitu 0,0, 0,5 dan $1 \mathrm{ppm}$. Hasil penelitian menunjukkan bahwa 2 ppm 2,4-D, 3 ppm 2,4-D, 4 ppm 2,4-D, 2 ppm 2,4-D + 0,5 ppm kinetin menghasilkan eksplan daun muda durian melengkung dan tulang daun membengkak. Pada perlakuan 5 ppm 2,4-D, 2 ppm 2,4-D +1 ppm kinetin, 5 ppm 2,4-D 5 ppm +1 ppm kinetin menghasilkan eksplan daun muda durian menggulung dan membentuk kalus.
\end{abstract}

Kata Kunci: Durian Kamajaya, Kultur jaringan, Zat pengatur tumbuh 


\section{PENDAHULUAN}

Provinsi Jawa Barat merupakan salah satu provinsi penting sebagai salah satu produsen buahbuahan di Indonesia, salah satunya adalah durian. Durian Kamajaya merupakan salah satu varietas lokal yang dikembangkan di Kota Cimahi yang berasal dari daerah Kamarung, Kelurahan Citeureup, Kecamatan Cimahi Utara. Durian varietas Kamajaya memiliki keunggulan yaitu tingkat kemanisan yang tinggi, biji dengan ukuran kecil, serta daging buahnya tebal. Durian ini dikembangkan dari satusatunya pohon durian varietas ini yang masih tersisa dan telah berusia kurang lebih 120 tahun (DIKPLHD Kota Cimahi, 2019).

Permasalahan utama dalam pengembangan durian varietas Kamajaya adalah ketersediaan bibit yang sangat terbatas sehingga saat ini tanaman durian Kamajaya hanya dapat diperoleh dari satu pohon induk yang terdapat di daerah Kamarung. Selain itu kondisi tanaman durian varietas Kamajaya saat ini masih diperbanyak dengan teknik konvensional yaitu dengan pengambilan entres dan okulasi entres dari tanaman induk. Perbanyakan tanaman secara konvensional seringkali tidak efektif karena dapat merusak pohon induk. Oleh karena itu, cara yang terbaik untuk memperbanyak tanaman durian dapat dilakukan dengan kultur jaringan untuk konservasi plasma nutfah buah-buahan lokal khususnya durian Kamajaya asal Cimahi (Rahmadi dkk., 2020).

Bioteknologi tanaman menghasilkan metodologi baru untuk dapat meningkatkan produksi benih yang berkualitas dalam jumlah banyak dan terus menerus yaitu dengan teknik kultur jaringan. Perbanyakan tanaman dengan teknik kultur jaringan dapat dilakukan melalui induksi organogenesis atau embriogenesis somatik. Dengan cara induksi embriogenesis somatik memungkinkan mendapat hasil jumlah propagul seragam dalam waktu yang singkat (Zulkarnain et al., 2013).

Perbanyakan durian melalui kultur jaringan tanaman sangat terbatas dikarenakan masalah kontaminasi yang disebabkan bakteri dan jamur dan masalah lainnya adalah pencoklatan atau browning yang terjadi pada eksplan daun maupun tunas tanaman durian. Menurut Royani (2016) perbanyakan durian selama ini dilakukan secara generatif dengan biji dan secara vegetatif dengan penempelan, okulasi, penyusuan dan hasil durian secara kultur jaringan belum pernah dilaporkan berhasil menumbuhkan planlet hasilnya hanya sebatas pada optimasi sterilisasi, inisiasi kalus dan embriogenik kalus.

Hasil penelitian Supangkat dkk., (2005) tingkat kontaminasi pada eksplan daun muda durian mencapai presentase hidup hanya 50\% dikarenakan masalah sterilisasi daun muda durian. Kontaminasi pada daun daun durian disebabkan karena adanya bulu halus atau pilosus pada permukaan abaksial daun dan di permukaan kulit batang menyebabkan daun durian sulit dilakukan sterilisasi (Widiastuti dkk., 2018). Sterilisasi eksplan durian sulit dilakukan pada eksplan dikarenakan terdapatnya lendir yang banyak pada eksplan tunas dibandingkan dengan eksplan daun, eksplan tersebut membuat larutan bakterisida dan fungisida tidak efektif menghilangkan kontaminan (Royani, 2016).

Zat pengatur tumbuh merupakan senyawa organik yang dapat memengaruhi pertumbuhan dan perkembangan tanaman. Zat pengatur tumbuh dalam media kultur sangat penting karena peranannya dalam mendorong atau menghambat pertumbuhan dan menentukan arah perkembangan eksplan maupun bahan tanaman yang dikulturkan (Hapsoro \&Yusnita, 2018)

Pengaruh zat pengatur tumbuh dalam pembentukan kalus telah dilaporkan, seperti pada penelitian Sugiyanto \& Kuswandi (2013) menunjukkan bahwa dengan penambahan BAP dalam media Murashige and Skoog (MS) dapat memicu pertumbuhan tunas pada eksplan nodia durian pada konsentrasi 2 dan 4 ppm. Penambahan 2,4-D mampu menginduksi kalus pada daun durian. Pada konsentrasi 1 ppm kalus yang dihasilkan berwarna putih, berair dengan daun yang tidak terlalu menggulung sedangkan konsentrasi 0,4 dan 1,5 ppm menghasilkan kalus hijau dengan daun yang menggulung. Handayani et al. (2019) menunjukkan bahwa dengan penambahan kinetin $0,5 \mathrm{ppm}$ mendapatkan hasil yang terbaik untuk induksi kalus pada daun durian. Penelitian ini bertujuan untuk mendapatkan kombinasi 2,4-D dan Kinetin yang terbaik dalam menginduksi kalus dari eksplan daun muda durian Kamajaya.

\section{BAHAN DAN METODE}

Penelitian dilakukan di Laboratorium Kultur Jaringan Tanaman Fakultas Pertanian Universitas Padjadjaran Jatinangor dari bulan Maret sampai Oktober 2020. Bahan yang digunakan adalah daun muda durian varietas lokal asal Cimahi yaitu varietas 
'Kamajaya'. Media yang digunakan berupa media dasar Murashige and Skoog (MS).

Eksplan daun disterilisasi dengan air mengalir selanjutnya direndam dalam detergen selama 30 menit lalu dibilas dengan aquadest steril. Kemudian eksplan daun tersebut direndam dalam larutan fungisida (Dithane) selama 60 menit lalu dibilas dengan aquadest steril. Langkah berikutnya adalah perendaman dalam larutan bakterisida (Agreft) selama 60 menit lalu dibilas dengan aquadest steril. Perendaman selanjutnya dilakukan dalam lautan Clorox 5\% selama 20 menit lalu dibilas dengan aquadest steril. Terakhir eksplan daun direndam dalam alkohol $70 \%$ selama 5 menit lalu dibilas dengan aquadest steril dan eksplan siap ditanam.

Rancangan penelitian ini menggunakan Rancangan Acak Lengkap (RAL) dengan perlakuan kombinasi 2,4-D (1, 2, 3, 4, 5 ppm) dan Kinetin (0, 0.5, $1 \mathrm{ppm})$. Setiap perlakuan terdiri dari 3 botol kultur tiap botol kultur ditanam 1 eksplan. Eksplan dikulturkan pada media induksi selama 8 Minggu. Pengamatan dilakukan terhadap kontaminasi oleh bakteri dan jamur dan presentase eksplan berkalus. Penelitian ini dianalisis menggunakan metode deskriptif eksplanatif untuk menggambarkan dan menjelaskan kondisi eksplan daun setelah diberi perlakuan media dan zat pengatur tumbuh.

\section{HASIL DAN PEMBAHASAN}

Ciri-ciri dari pembentukan kalus yaitu diawali dengan terjadinya pembengkakan pada permukaaan eksplan daun serta daun menggulung selanjutnya disusul dengan terbentuknya kalus pada pinggir daun atau tulang daun akibat dari perlukaan, karena pertulangan daun merupakan daerah penyalur makanan ke seluruh bagian permukaan daun sehingga sel yang terdapat dekat dengan pertulangan daun dapat membentuk kalus (Lizawati dkk., 2012). Hasil pengamatan menunjukkan bahwa pemberian beberapa kombinasi zat pengatur tumbuh 2,4-D dan Kinetin ke dalam media kultur MS sudah mampu memacu melengkungnya daun, membengkaknya tulang daun, menggulung dan membentuk kalus eksplan pada daun muda durian Kamajaya. Hasil pengamatan inisiasi eksplan daun muda durian Kamajaya ditampilkan pada Tabel 1.

Tabel 1. Inisiasi eksplan daun muda durian Kamajaya dengan penambahan zat pengatur tumbuh auksin (2,4D) dan sitokinin (kinetin)

\begin{tabular}{|c|c|c|c|c|c|}
\hline \multicolumn{2}{|c|}{ Kombinasi Perlakuan (ppm) } & \multirow{2}{*}{ Hidup (\%) } & \multirow{2}{*}{$\begin{array}{c}\text { Kontaminasi } \\
(\%)\end{array}$} & \multirow{2}{*}{$\begin{array}{c}\text { Browning } \\
(\%)\end{array}$} & \multirow{2}{*}{ Keterangan } \\
\hline $2,4-\mathrm{D}$ & Kinetin & & & & \\
\hline 1 & \multirow{5}{*}{0} & 0 & 0 & 100 & - \\
\hline 2 & & 33,3 & 0 & 66,6 & $\begin{array}{l}1 \text { eksplan daun melengkung, } \\
\text { tulang daun membengkak }\end{array}$ \\
\hline 3 & & 100 & 0 & 0 & $\begin{array}{l}2 \text { eksplan daun melengkung, } \\
\text { tulang daun membengkak }\end{array}$ \\
\hline 4 & & 100 & 0 & 0 & $\begin{array}{l}1 \text { eksplan daun melengkung, } \\
\text { tulang daun membengkak }\end{array}$ \\
\hline 5 & & 100 & 0 & 0 & $\begin{array}{c}1 \text { eksplan menggulung dan } \\
\text { membentuk kalus }\end{array}$ \\
\hline 1 & \multirow{5}{*}{0,5} & 66,6 & 0 & 33,3 & - \\
\hline 2 & & 100 & 0 & 0 & $\begin{array}{l}2 \text { eksplan menggulung dan } \\
\text { membentuk kalus }\end{array}$ \\
\hline 3 & & 100 & 0 & 0 & - \\
\hline 4 & & 100 & 0 & 0 & - \\
\hline 5 & & 100 & 0 & 0 & $\begin{array}{c}1 \text { eksplan daun melengkung, } \\
\text { tulang daun membengkak }\end{array}$ \\
\hline 1 & \multirow{5}{*}{1} & 66,6 & 33,3 & 0 & - \\
\hline 2 & & 100 & 0 & 0 & - \\
\hline 3 & & 100 & 0 & 0 & - \\
\hline 4 & & 66,6 & 0 & 33,3 & - \\
\hline 5 & & 66,6 & 33,3 & 0 & $\begin{array}{l}1 \text { eksplan menggulung dan } \\
\text { membentuk kalus }\end{array}$ \\
\hline
\end{tabular}

Keterangan: (-) eksplan tidak ada yang menggulung 
Media MS (Murahige dan Skoog) yang mengandung zat pengatur auksin 2,4-D menyebabkan eksplan daun menggulung tapi belum membentuk kalus pada eksplan daun muda pada perlakuan 2 ppm 2,4-D, 3 ppm 2,4-D, 4 ppm 2,4-D, dan 5 ppm 2,4-D hasil yang diperoleh menunjukkan bahwa pengaruh secara mandiri 2,4-D menyebabkan menggulungnya eksplan daun durian. Menurut Wahyuni, dkk. (2014) eksplan daun yang melekung dan tulang daun yang membengkak disebabkan oleh adanya pengaruh auksin 2,4-D dan tekanan tugor. Adanya auksin 2,4-D menyebabkan dinding sel mengendur disebabkan adanya sekresi asam dengan mengaktifkan suatu enzim pada $\mathrm{pH}$ tertentu dan merenggangnya sel akan menyebbakan pemanjangan sel. Senyawa 2,4-D diketahui dapat menginduksi perbanyakan sel dan menekan diferensiasi tanaman dikotil (Yuwono, 2006).

Menurut Purba \& Astawa (2017), pembengkakan pada eksplan daun terjadi karena adanya pengaruh pemberian 2,4-D merupakan suatu proses pertumbuhan setelah terjadinya proses pelengkungan akibat penyerapan air dan nutrisi dari media tanam. Kemudian selanjutnya akan disertai dengan tahapan perbanyakan sel. Dengan demikian, sel tanaman memiliki kemampuan untuk menyerap air dan unsur hara sehingga menyebabkan terjadinya pembengkakan jaringan.

Pengaruh rangsangan auksin terhadap perkembangan sel menunjukkan adanya indikasi bahwa auksin dapat menaikkan tekanan osmotik, meningkatkan sintesa protein, serta meningkatkan permeabilitas sel terhadap air. Kemudian akan terjadi pelunakan dinding sel yang diikuti menurunnya tekanan dinding sel sehingga air dapat masuk ke dalam sel yang disertai dengan naiknya volume sel (Hendaryono \& Wijayani, 1994).

Pada perlakuan 2 ppm 2,4-D, 3 ppm 2,4-D, 4 ppm 2,4-D, 2 ppm 2,4-D + 0,5 ppm kinetin menunjukkan bahwa pemberian 2,4-D dan beberapa kombinasi zat pengatur tumbuh antara 2,4-D dan kinetin ke dalam media kultur mampu memacu eksplan daun muda durian melengkung dan tulang daun membengkak. Sementara itu, pada perlakuan 5 ppm 2,4-D, 2 ppm 2,4-D + 1 ppm kinetin, 5 ppm 2,4D 5 ppm + 1 ppm kinetin mampu memacu eksplan daun muda durian menggulung dan membentuk kalus (Gambar 1). Kalus dihasilkan dari lapisan luar sel-sel korteks pada eksplan melalui pembelahan sel yang berulang-ulang dan berkembang lebih lambat disbanding kultur yang berasal dari suspense sel (Yuwono, 2006).

Pemberian zat pengatur tumbuh sitokinin dalam media kultur jaringan penting untuk menginduksi perkembangan dan pertumbuhan eksplan (Zulkarnain et al., 2013) serta penambahan zat pengatur tumbuh auksin dalam jumlah yang lebih besar atau stabil seperti 2,4-D cenderung akan menyebabkan terjadinya pembentukan kalus (Wetherell, 1982). Zat pengatur tumbuh sitokinin berpengaruh terhadap pembelahan sel dan auksin memberikan pengaruh interaksi terhadap diferensiasi jaringan (Hendaryono \& Wijayani, 1994).
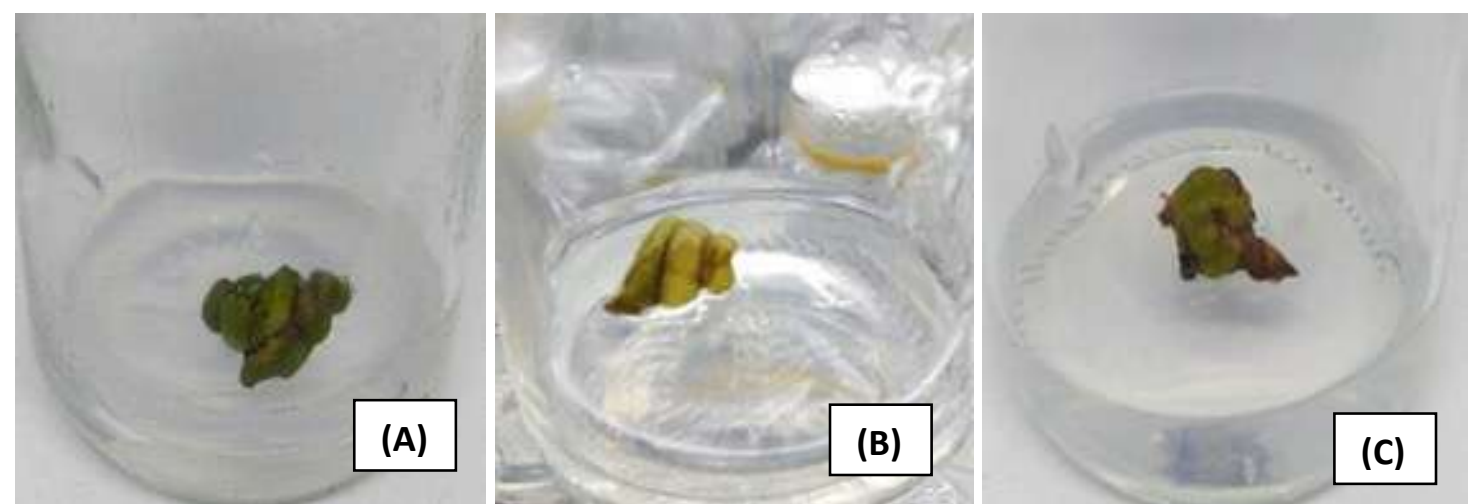

Gambar 1. Perlakuan eksplan daun pada media MS dengan tambahan. (A) 5 ppm 2,4-D. (B) 2 ppm 2,4-D + 1 ppm kinetin. (C) 5 ppm 2,4-D + 1 ppm kinetin.majemuk tablet NPKMg + disiram, $\mathrm{H}=90$ $\mathrm{g} /$ tanaman majemuk tablet NPKMg + ditabur, $\mathrm{I}=90 \mathrm{~g} /$ tanaman majemuk tablet NPKMg + disiram.

Pada perlakuan 1 ppm 2,4-D + 1 ppm kinetin dan 5 ppm 2,4-D + 1 ppm kinetin terdapat eksplan hidup mencapai presentase $66,6 \%$ sedangkan eksplan terkontaminasi mencapai presentase 33,3\%.
Kontaminasi disebabkan oleh jamur yang ditandai oleh hifa-hifa berwarna putih yang menyerang bagian bawah maupun atas eksplan daun muda durian (Gambar 2A) memperlihatkan bahwa 
kontaminasi disebabkan oleh jamur ditandai dengan adanya koloni jamur kemudian menyebar di media tanam eksplan berwarna putih. Jamur dapat muncul pada eksplan atau dari spora yang berada di udara dan struktur hifa jamur beragam warnanya (Mastuti, 2017).

Pada perlakuan 1 ppm 2,4-D eksplan mengalami pencoklatan atau browning (Gambar 2B) mencapai 100\%, perlakuan 2 ppm 2,4-D mencapai $66,6 \%$ dan perlakuan 1 ppm 2,4-D + 0,5 ppm kinetin serta 4 ppm 2,4-D + 1 ppm kinetin eksplan masingmasing mencapai 33,3\%. Terdapat banyak faktor yang menyebabkan terjadinya browning pada eksplan seperti yang dijelaskan Hutami (2008) perubahan warna menjadi coklat (browning) dalam kultur jaringan tanaman terjadi karena akumulasi polifenol oksidase yang dilepas atau disintesis jaringan dalam kondisi teroksidasi ketika sel dilukai, jaringan yang diisolasi menjadi berwarna coklat atau berubah menjadi kehitaman dan akhirnya eksplan gagal untuk tumbuh. Sintesis senyawa fenol yang menutupi seluruh permukaan eksplan daun muda durian dapat menghambat pertumbuhan kalus bahkan dapat menyebabkan gagal tumbuh atau kematian pada eksplan.

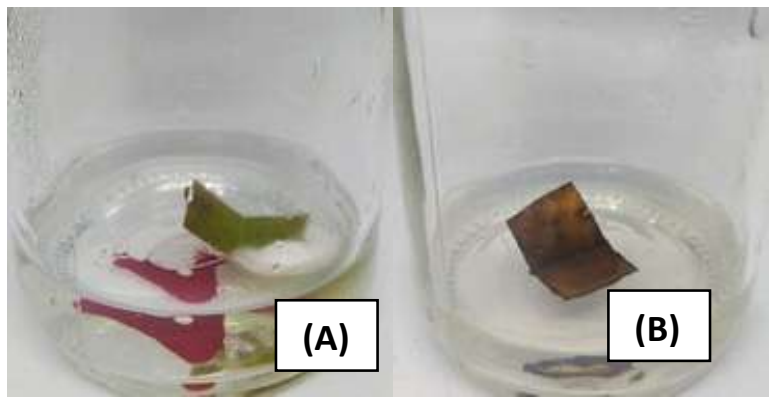

Gambar 2. Kegagalan tumbuh pada eksplan daun durian. (A) Eksplan daun terkontaminasi jamur. (B) Eksplan daun mengalami browning (pencoklatan).

\section{SIMPULAN}

Pemberian beberapa konsentrasi zat pengatur tumbuh yang diberikan pada Media MS dengan zat pengatur tumbuh kombinasi antara auksin dan sitokinin 2 ppm 2,4-D, 3 ppm 2,4-D, 4 ppm 2,4-D, 2 ppm 2,4-D + 0,5 ppm kinetin menghasilkan eksplan daun muda durian melengkung dan tulang daun membengkak. Sementara itu, pada perlakuan 5 ppm 2,4-D, 2 ppm 2,4-D + 1 ppm kinetin, 5 ppm 2,4-D 5 ppm +1 ppm kinetin menghasilkan eksplan daun muda durian menggulung dan membentuk kalus.

\section{UCAPAN TERIMA KASIH}

Ucapan terima kasih kami sampaikan ke semua pihak yang telah membantu penyelesaian penelitian, dan kepada Ditjen Dikti untuk mendukung pekerjaan ini melalui hibah pada skema Hibah Thesis No. 1827/UN6.3.1/LT/2020. Kami juga berterima kasih Pemda Cimahi yang sudah menyediakan ekplan durian Kamajaya dan kepada semua anggota laboratorium kami untuk diskusi bermanfaat selama bekerja.

\section{DAFTAR PUSTAKA}

DIKPLHD Kota Cimahi. 2019. Buku II Laporan Utama. Kementerian Lingkungan Hidup Dan Kehutanan. Tersedia online pada: https:/cimahikota.go.id/uploads/data/buku1.pdf. Diakses 18 Juli 2019.

Handayani, RS, I Yunus, M Sayuti, and E Irawan. 2019. In-vitro callus induction of durian (Durio zibethinus Murr.) leaves using kinetin and 2,4-D (Dichlorophenoxyacetic acid). Journal of Tropical Horticulture. 2(2): 59-64.

Hapsoro, D, dan Yusnita. 2018. Kultur Jaringan: Teori dan Praktik. Penerbit Andi. Yogyakarta. ISBN 978-979-29-7189-7.

Hendaryono, D, dan A Wijayani. 1994. Teknik Kultur Jaringan Pengenalan dan Petunjuk Perbanyakan Tanaman Secara VegetatifModern. Kanisius. Yogyakarta.

Hutami, S. 2006. Penggunaan arang aktif dalam kultur in vitro. Berita Biologi. 8(1): 83-89.

Lizawati, Neliyati, dan R Desfira. 2012. Induksi kalus eksplan daun durian (Durio zibethinus Murr. cv. Selat Jambi) pada beberapa kombinasi 2,4-D dan BAP. 1(1): 19-25.

Purba, RV, dan ING Astawa. 2017. Induksi kalus eksplan daun tanaman anggur (Vitis vinivera L.) dengan aplikasi 2 , 4-D secara in vitro. E-Jurnal Agroekoteknologi Tropika. 6(2): 218-228.

Rahmadi, A, N.Wicaksana, B Nurhad., E Suminar, SRT Pakki, S Mubarok. 2020. Optimasi teknik sterilisasi dan induksi tunas tanaman durian (Durio zibethinus Murr) 'Kamajaya' lokal Cimahi secara in vitro. Jurnal Kultivasi. 19(1): 1083-1088. 
Royani, JI. 2016. Kajian inisiasi tunas durian (Durio zibethinus Murr) secara in vitro. Prosiding Kongres Teknologi Nasional. Jakarta.

Sugiyanto, L dan PC Kuswandi. 2013. Eksplorasi metode sterilisasi dan macam media untuk perbanyakan durian (Durio zibethinus, L.) secara in vitro. Sains Dasar. 2(1): 20-24.

Supangkat, G, IA Rineksane, dan K Pamuji. 2005. Sterilisasi dan induksi daun muda durian (Durio zibethinus) dalam medium MS dengan penambahan kinetin dan IAA secara in vitro. Planta Tropika. 1: 34-38.

Wahyuni, KD, D Prasetyo, dan S Hariyanto. 2014. Perkembangan kultur daun Aglaonema sp. dengan perlakuan kombinasi zat pengatur tumbuh NAA dan 2,4-D dengan BAP. Jurnal Bioslogos. 4(1): 9-16.
Widhiastuti, Y, K Bariyah, $\mathrm{P}$ Istianingrum, $\mathrm{S}$ Hartatik, DP Restanto. 2018. Metode sterilisasi eksplan durian merah Banyuwangi secara in-vitro. Prosiding Seminar Nasional PPM Unesa. Surabaya. Hlm. 1586-1592.

Wetherell, DF. 1987. Pengantar Propagasi Tanaman secara In vitro. Terjemahan: Koensumardiyah. Avery Publishing Group Inc. Wayne, New Jersey.

Yuwono, T. 2006. Bioteknologi Pertanian. Gadjah Mada Press. Yogyakarta.

Zulkarnain, Neliyati, and Lizawati. 2013. Callus proliferation from immature leaf explants of durian (Durio zibethinus Murr. cv. Selat) with the addition of picloram and BAP. Jurnal Hortikultura Indonesia. 4(3): 107114. 